\title{
Muslim Fashion: Challenging Transregional Connectivities between Malaysia and the Arabian Peninsula
}

\author{
Viola Thimm* (1) \\ University of Heidelberg, Germany \\ ${ }^{\star}$ Corresponding author. Email: viola.thimm@uni-heidelberg.de
}

(Received 7 June 2020; revised 4 January 2021; accepted 4 January 2021)

\begin{abstract}
In Malaysia, a Muslim-majority country in Southeast Asia, a dynamic market for Muslim fashion has evolved over the past decade, especially concerning the abaya, a female Muslim dress. Malay Malaysian designers, producers and consumers focus on this garment because it represents a style of female Islamic clothing that is perceived as 'authentic'. The abaya originates from the Arabian Peninsula and is generally worn by Arabic Muslim women with a syariah-compliant design that is commonly simple, loose and opaque. Embedded into the broader marketising processes of a halal industry in Malaysia, Malay women started to adopt this material object and transformed it into a distinct expression of Malaysian Muslim style. The original abaya that follows Islamic rules became a colourful and decorated dress. This transformative process is not only an expression of variation in fashion and style but profoundly transcends powerful social, placial and spatial orders within the Muslim world. The Malaysian fashion market for abayas is embedded in wider dynamics of sacred landscaping in which the Arabian Peninsula is considered to be the 'centre of Islam' while Malaysia is positioned and positions itself at the margins. However, Malay Malaysian social actors have shifted this constellation towards a Malaysia that has pushed itself to the forefront of a commercialising Islam through the development of the related Muslim fashion market, among other things. Thus, within a Muslim world order, transregional connections lead to an entangled web of meaning-making regarding power structures, Islamic principles and social practices.
\end{abstract}

Keywords: Islam; fashion; transregionalism; mobility; abaya; halal economy

\section{Mapping the Field}

Over a dinner comprised of Arabic manakeesh (flat round baked dough topped with thyme, sesame, cheese, vegetables or meat) and koshary (an Egyptian dish made of lentils, noodles, rice, onions, tomato sauce and spices) at 1Utama, a big shopping mall near Malaysia's capital Kuala Lumpur (KL), Uswah, ${ }^{1}$ a Malay Malaysian woman who grew up in Saudi Arabia, told me: "The first time I came here to Malaysia was when I was aged 12. At that time [in 1994], no one knew about Arabic culture. Only maybe the village people, for them we were more blessed by God because we came from Saudi Arabia" (22 August 2017). This brief statement shows, inter alia, that according to Malaysian rural inhabitants, the geographical place of Saudi Arabia is linked to a religious meaning. More precisely, it reveals that this particular place is saturated with spiritual Islamic meaning, in contrast to the Malaysian rural areas themselves. This paper deals with a specific 'placial' (Gielis 2009) and 'spatial' (Anthias 2012) ordering of the Muslim world and its connection to a transregional market economy targeting Muslims, especially from the perspective of Malaysia as part of the so-called 'Muslim periphery', focusing on a Muslim fashion market that has evolved between the Arabian Peninsula, or more precisely, the United Arab Emirates, and Malaysia that revolves around a female Muslim dress.

\footnotetext{
${ }^{1}$ All names, either personal or corporate, are pseudonyms.

(c) The Author(s), 2021. Published by Cambridge University Press on behalf of Institute for East Asian Studies, Sogang University. This is an Open Access article, distributed under the terms of the Creative Commons Attribution licence (http://creativecommons.org/licenses/by/4.0/), which permits unrestricted re-use, distribution, and reproduction in any medium, provided the original work is properly cited.
} 
Malaysia is a multicultural society where 68.6 per cent of the citizens are classified as Bumiputera (Malays and native people, such as Orang Asli or Kadazandusun), 23.4 per cent of Chinese ancestry and seven per cent of Indian ancestry (Department of Statistics, Malaysia 2016). According to the Malaysian Constitution, social, political and economic advantages favour the Malays (Federal Constitution Malaysia, n.d.), albeit with certain restrictions. Furthermore, the Constitution specifies Sunni Islam as the religion of the state (Hefner 2001: 29) and, interestingly, as the obligatory religion for all Malays (article 3 [1]: 160). Consequently, after independence from British colonialism (Gunn 2008; Huff 1994; Ooi 2009), Islam was established with special protection as the religion for the majority of society during the process of nation-building, and this has been retained by the government to the present day.

Contemporary Malaysian state policies are embedded in processes of Islamic revivalism (Frisk 2009; Müller 2014; Ufen 2008), modernisation (Hefner 2001: 30; Norani 1998), and the emergence of a local Malay middle class (Chong 2005; Kahn 1996; Kessler 2001; Norani 1998; Saravanamuttu 2001; Sharifa 2001). Modernisation strategies were implemented in Malaysia in the 1970s and 1980s with the introduction of the New Economic Policy (NEP) in 1971 as a starting point. The NEP aimed at economic development for the Malay population through the improvement of educational and job opportunities. These successful economic policies eventually yielded a Malaysia with a tiger economy (Derichs 2007; Lafaye de Micheaux 2017). During these processes, a new Malay Malaysian middle class, with distinctive male and female elements, developed (Norani 1998: 173) along with increasing consumption (Fischer 2008). Evolving individualism and materialism formed the background for practices such as going shopping (Fischer 2008: 160f.). On the basis of these entangled dynamics around Islam and Malaysia's economic rise, a local and transregional market for consumer goods perceived as Islamic began to grow (Fischer 2018) and is demonstrated by the recently developed Muslim fashion economy.

My enquiry for this article is guided by the following questions: (1) How do Malay Malaysian people make sense of physical locations to which they ascribe Islamic meaning and related goods? (2) Which social and economic realms target these places? (3) What kind of transregional connectivities grow out of these dynamics? To anticipate the answers, in Malaysia and on the Arabian Peninsula alike, Saudi Arabia and the Arabic region as a whole are regarded as the heart of the Islamic world, primarily due to Islamic history (Ansary 2010). With this understanding, Southeast Asia is perceived as being located at the Islamic margins. This spiritual place-making of certain physical locations in the world has deep effects on processes of meaningmaking relating to objects that come from these regions. My Malay Malaysian respondents consider not only the people, as mentioned by Uswah, but also anything material from the Arabian Peninsula as especially Islamic. This meaning-making is reinforced for objects or goods connoted as Islamic, such as garments that comply with religious rules. However, Malay Malaysian social actors do not solely obey Islamic style from the Arabian Peninsula but have also adopted and transformed elements of it, in particular the abaya, a female Muslim dress, incorporating it into their lifeworlds and thereby establishing their own market and habitual practices within the transregional space between Western and Southeast Asia.

This study is based on an ethnographic multi-sited (Marcus 1995) approach to fieldwork, data collection and analysis. This multi-sited approach implies doing fieldwork in diverse but linked places-in this case, in Malaysia and the United Arab Emirates (UAE) between December 2013 and April 2018 for a total of 14 months. In sum, 277 qualitative interviews, discussions and conversations in various forms and lengths were conducted with 217 people. However, not all of these interviews focused on transregional connectivities through Muslim fashion but were also related to broader research questions on Muslim mobility, gender and consumption (see Thimm 2015, 2017, 2018, 2021, forthcoming). The interviews were primarily open and narrative, and all of them were transcribed. Some of these interviews were recorded, some were not. In the latter cases, I took notes of verbatim statements by my respondents. Interviews were conducted either in Bahasa Melayu (Malay), English or local Manglish (a mixture between the two languages found especially in urban areas).

In what follows, I will first briefly showcase a discussion about the hierarchical landscaping of the Islamic world from the perspective of my Malay Malaysian respondents. After that, I will clarify my theoretical understanding of transregionalism, embedded in wider concepts of mobilities, space and place, as well as transnationalism and globalisation. Subsequently, developments that turned Malaysia into a hub for halal or syariah-compliant products will be traced, exemplified by the market for Muslim fashion. Originating from the Gulf, the abaya, as the main garment in this segment, has been designed, produced 
and consumed to ever-greater degrees in Malaysia. Based on an ethnographically thick example, this process will be discussed in relation to the transregional connectivities it derives from and actively shapes. These connectivities will ultimately be posited as challenging Muslim world orders, as a result of which, to a certain extent, Malaysia rises and the Arabian Peninsula declines.

\section{Discursive Narratives: Topological Place-Making in the Muslim World}

Based on my fieldwork observations, normative narratives stress notions of Arabic Islam as 'authentic'. In the Etihad Museum in Dubai, for example, visitors can read on a panel under the keyword 'Identity': "The Emirati identity is an Arab Islamic identity that is deeply rooted within the history of the Arab and Islamic world". As evident from Uswah's quote at the beginning of this article, not just Emiratis but also my Malay Malaysian respondents have internalised this narrative. My respondent Hamid expressed this condition in a nutshell during a conversation about pilgrimage: "Following Arab [culture, people] means following Sunnah [the sayings and deeds of the Prophet Mohammad] and this, in turn, means coming closer to God."

My Malay Malaysian respondents integrated different elements into their lives as strategies or practices to follow Arab culture with the aim of experiencing spiritual enhancement. One method is learning Arabic. Sitting in a mamak (Indian Muslim) stall over dinner in the neighbourhood where I lived during my fieldwork in KL, a Muslim Malay Malaysian man in his early thirties from the neighbouring table told me that he had to learn Arabic from early adolescence onwards. His mother had been convinced that the language would bring him closer to God. I asked him, “So, did it bring you closer to God?" He responded, "No!". Another way to follow Arab culture is to wear Arabic clothing. Thirty-year-old Annisa from the city of Melaka, who I met in Dubai during her trip to Islamic places in the Arabian region, mentioned in one of our conversations, "When we go back to Malaysia, we bring back abaya [female Muslim dress]". I asked: "Why the abaya?" Her husband Abdul responded, similar to Hamid, "Because as Muslims, we want to follow the Arab people. Because Islam is from here [the Arab region]. The Prophet [Mohammad] was from here, from Saudi" (27 January 2018).

The abaya is a long black dress or coat, originally worn by women from the Gulf (see below for details). Annisa prioritised this garment as a Malay Malaysian person to strengthen her relationship with God on the basis of its Arabic, and therefore Islamic, embeddedness.

This equation of 'Arabic culture' with authentic Islam is discursively contested in Malaysia, mostly under the keyword of 'Arabisation', by those who reject this approach. While sitting on a sofa framed by wood panels carved with Arabic patterns, Fatimah, a Malay Malaysian person in her late thirties who worked at a Government Linked Corporation (GLC), reflected upon these processes:

$[\mathrm{P}]$ eople take Arabs as a symbol of Islam which is actually wrong. This is what I mean by Arabisation. People see Arabs being the true Muslims, which is not even specifically mentioned in the Qur'an. Being a national of an Arab country doesn't mean that you are a Muslim, right? (...) Arabisation is that we as Malays have to have Arabic elements to signify that we are Muslims. (25 May 2017)

In agreement with Hamid, Annisa and Abdul, Fatimah understood 'Arabisation' as a perception among Malays that appropriating Arabic elements is a way to become more religious, yet she criticised this way of thinking. The negative stance towards this attitude was introduced by sociologist Syed Farid al-Attas in a public panel discussion on 'Arabisation' in May 2016 in Kuala Lumpur. He focused on a hierarchical notion between Malay Malaysians and Arabs in this regard: "For some reason the Malays often feel very low about themselves. So when they ape the Arabs they believe they are the more authentic (Muslims)" (Syed 2016).

That "Malays often feel very low about themselves" touches on notions of powerful Muslim landscaping in which world regions are mapped on the basis of grades of Islamic authenticity. This authenticity is grounded in an understanding of the whole Gulf region, and particularly the Hejaz, ${ }^{2}$ as the cradle of

\footnotetext{
${ }^{2}$ The Hejaz is part of today's Saudi Arabia and of relevance for Muslims because the holy places Mecca and Medina are located within this area.
} 
Islam. It is based on an entangled web comprising a perception of Mecca as the centre of the world, incidents in pre-Islamic Arabia that testify to the early spread of Islam and the peak phase of the Islamic empires that are located throughout the whole region (see King 2001). Within these sacred landscapes, Muslims in Southeast Asia, including Malaysia, are positioned (and position themselves) on the margins (Abaza 1996, 1999, 2007, 2011). Discursive narratives of the Arabian Peninsula as the exalted Islamic centre and of faraway places such as Malaysia or Indonesia as part of an inferior Islamic periphery have led to powerful dynamics within this transregional space on different social scales.

\section{Transregional mobilities in Muslim space}

This transregional space is constituted through forms of mobility that bring Malay Malaysians, especially from the local middle classes, to places abroad. Social mobility, based on educational and material resources, enables the subjects to turn their income into experiences in different geographical and sociocultural environments. One of the means for this practice is the use of the service good of travel packages (Thimm 2017). Access to transportation is crucial here. Thus, on the basis of the material resources involved and invested, social mobility allows for physical mobility, i.e., the subject's travel to a locality abroad.

Given this, global flows and mobilities are not equally possible, approachable and accessible for each individual but depend upon social status (e.g., Bauder 2014; Bonfanti 2016; Glick Schiller and Salazar 2013). To be able to afford an original 'Dubai abaya', as my Malay respondents call it, includes travelling to Dubai oneself and paying for a plane ticket, accommodation, the visa fee and the opportunity to go souvenir shopping; the means to do so have increased for a large percentage of Muslim Malaysians due to economisation and the rise of a 'new Malay middle class' in urban Malaysia since in the 1980s/1990s (Chong 2005; Kahn 1996; Kessler 2001; Norani 1998; Saravanamuttu 2001; Sharifa 2001). In the past, when Malay Muslims intended to travel to the Arab region, they often had to sell their land and property to afford the trip, especially fishermen and farmers from rural areas (kampungs) (Aiza 2014).

Mobility studies deal with the manifold ways in which people get involved in global, transnational or transregional networks, or how they are excluded from them, and how people and objects cross time and space (Hannam et al. 2006: 12; Salazar 2016: 3). This approach acknowledges that human movements are better analysed and understood with and not in contrast to other types of movements, considering not only human movements, but also the massive flows of capital-as in the global halal market (see below) - and goods such as religiously connoted garments and styles which are, simultaneously, an expression, trigger and result of globalisation, transnationalism and transregionalism.

Processes of globalisation, which are evident in new information technology and infrastructure, induce 'time-space compression' (Harvey 1969; see Massey 2001: 146-156) and hence, spatial and temporal overlaps and entanglements. New perceptions of geographical distances and social relationships between people over such distances are constantly developing. Social relationships and spiritual encounters can now be maintained over hundreds or thousands of kilometres. Through telecommunications and the World Wide Web, the hurdles of time difference and geographical distance are reduced with one click when, for example, Muslim Malaysians order their abayas online in Dubai to be delivered across the Indian Ocean only a few days later. Likewise, due to developments in technology and the travel industry, Malaysian abaya designers can fly to Dubai to purchase the special cloth for abayas (nida emirates) over a weekend-a trip that lasted around three months from the Malay Archipelago to the Arabian Peninsula forty years ago, when it had to be undertaken by ship (Bunnell 2016). As technology goes beyond borders, so does the abaya, as an element of current 'time-space compression'.

The global space reminds us that social debates and practices are not locally split but transcend regional and national borders and boundaries. Applying a transnational lens to these networks provides a way to stipulate that social relations are localised in at least two nation-states (Basch et al. 1997) and evolve via circular mobility, i.e., when physical human movement recurs episodically or periodically. In this way, different places are materialised in national territories and become connected. The transnational social space is therefore not bound to one geographical location but rather is distributed over several national localities that are shaped by different relationships imbued with power over one another through dynamic social and cultural ties (Basch et al. 1997). 
Critiques of the transnational concept target its focus on the nation-state as the main frame of reference and analysis (e.g., Anthias 2012; Boccagni 2012; Göler and Krišjāne 2016). One outcome of this is that social ties and connected places within nation-states are underestimated in the framework of transnationalism. Following this critique, I rather draw on a transregional optic here: The contemporary dynamics between the nation-states of Malaysia and Saudi Arabia that I want to trace through the example of the Muslim fashion market are embedded in much broader historical connections that reach back to a time before nation-states as concepts and practices even existed. Muslims from the Malay Archipelago have made their way to the Arabian Peninsula with the Hejaz as their desired destination ever since Islam has existed, particularly for Muslim pilgrimage (hajj), but additionally for trade (e.g., Aiza 2014; Bunnell 2016; Tagliacozzo 2013; Yeoh 2016).

Such historical, socio-political and economic circumstances thus highlight the need to go beyond national and transnational boundaries and to include myriad forms of translocal and transregional connections in analysis on different socio-political, economic, cultural or historical scales. Connectivities, then, are not only studied through the political and territorial lens of the nation-state but furthermore through socio-structural factors that equally shape mobility. In a similar vein, Anthias (2012: 103) argues,

Alongside a transnational and national focus, (...) we can [furthermore] refer to the local, the translocal and the translocational. This is important because there is then a space to study trans-ethnic and transnational relations in a range of contexts that include the local and the national as well as the transnational level of analysis. Trans-ethnic connections point to relations between different ethnically constructed groups building on similar experiences, goals and trajectories. For example, what are the networks across ethnic divides and what forms of solidarity exist outside those of ethnicity?

Since the abaya is explicitly understood as culturally-or, in Anthia's words, ethnically-Arabic and not Malay, and as it is increasingly worn in Malaysia, as indicated above, it has the potential to become a means of building up such a network across ethnic (and other) divides. Malay Malaysian Muslims such as Hamid, Abdul or Annisa negotiate culturally or ethnically Arabic elements as part of their everyday lifeworlds, appropriate corresponding narratives ('coming closer to God'), ideologies (Islam is where the Prophet lived) and objects (abaya) perceived as 'authentically Arabic', assign meaning to them and carry them through the transregional space from the Arabian Peninsula to Malaysia or distribute them within this space.

Both the type of connectivities (here: transregional) and the entailing space can be understood in different ways. Space can either be a place and territory of social order, i.e., acknowledged in a structural and therefore topological way, or a place of the material conditionality of the social order and, consequently, regarded in a topographic manner (see for example Harvey 1969; Löw 2001; Schroer 2006; Werlen 1987, 2010). The transregional space between Malaysia and the Arabian Peninsula is, in this case, topologically constituted as it is mapped through imaginations, discourses, goods, objects and social practices that form people's lifeworlds.

This topological condition grows, inter alia, through the object of the abaya and is thereby shaped by social and material dimensions (see Sen and Silverman 2014: 4). Hence, spaces are not only constituted through social relations and social action (Lefebvre 1991 [1974]; Löw 2001; Massey 2001; Schroer 2006; Werlen 1987) but 'religious spaces' (see Knott 2014) especially become tangible through materiality. This can be objects and things (Meyer and Houtman 2012), like a female dress perceived as religious, or geographical places in which social spaces are lived in, like Mecca, the Hejaz or the Gulf region. This form of physical locality is produced by historicity and by socio-political and economic structures, as expressed in the example of Malay Malaysians traveling to the Arabian Peninsula for both pilgrimage and trade (Feener and Sevea 2009). The socio-spatial relationships reflect territorially based mechanisms that create, maintain and transform different regional and transregional discourses (Werlen 2010), such as that on Arabisation, for example.

The form and degree to which discourses, people, goods, ideologies or oneself are set into motion and that controls this process is what Massey (2001) called 'power geometry'. The unequal condition that forms the background for the degree requires, according to Massey (2001: 150), a political agenda, because power geometry 
is not simply a question of unequal distribution, that some people move more than others, and that some have more control than others. It is that the mobility and control of some groups can actively weaken other people. Differential mobility can weaken the leverage of the already weak. The timespace compression of some groups can undermine the power of others.

The time-space compression in the Malaysian context opens up a social space in which Muslims in Southeast Asia shape, negotiate and transform their social, political and economic positions. As we shall see in the following, this undermines the power of the self-proclaimed 'Islamic centre' and thereby challenges hierarchical orderings of the Muslim world into the centre and its margins (see Derichs 2014). As such, power geometry has the potential to upset classical topological orders.

\section{Malaysia as a halal Hub}

Within this topological order, in which the Arab region is perceived as an elevated spiritual centre and Southeast Asia as an insufficiently Islamic periphery, identities are shaped, negotiated and contested. The Malaysian Self is defined and negotiated through the Arabic Other, as touched upon by Annisa, Abdul and Fatimah, but also through the Western Other. The global Western world order has been constituted on the basis of differentiation from 'the threatening Muslim Other' since the early 2000s and thereby degrades anything (classified as) Islamic (El-Tayeb 2016). From this twofold diminished position, Malay Malaysians appropriate Arabic-Islamic values, traditions and practices they consider to be sublime. However, they simultaneously appropriate Western values and practices in the forms of neoliberalism and consumption, for example (Fischer 2008, 2018).

Consequently, a reversal of the ordering of the Muslim periphery has evolved over the past fifteen years, locating Malaysia at the heart of Islamic modernity as it has become the hub for the world halal ['allowed' according to syariah law, in contrast to haram, i.e., 'forbidden'] economy. For instance, Malaysia was at the vanguard of developing a halal certification system (Aiedah 2018), which was only recently adopted by Arab Gulf states. Furthermore, GLCs developed an Islamic finance system in Malaysia (Rudnyckyj 2019) that functions as a role model for other Islamic or Muslim-majority states. Additionally, Malaysia's halal industry has been internationally recognised, ranked number one for 'Islamic tourism' by the Singapore-based CrescentRating for the past decade. ${ }^{3}$ Due to these manifold cornerstones, Malaysia is now acknowledged as a modern Islamic centre even by the government of Saudi Arabia, the state that administers and oversees the holiest places of Islam. This was evident, for example, when the Arabic state started to officially offer tourism visas for Malaysian citizens in 2018 in the course of the 'After Umrah [minor pilgrimage] Program'. ${ }^{4}$ By this means, Malaysia was the first country ever to be offered tourist visas by Saudi Arabia. Clearly, with its modernising transformation into a halal hub, Malaysia has located itself at the epicentre of a marketed Islam.

This manifest socio-political and spatial self-positioning of the Southeast Asian state points to the fact that Muslims do not only cross space - physically, imaginatively, virtually-on the basis of their belief, but they also $d w e l l$ in space, as Tweed (2008: 75) conceptualises it: "[R]eligions help the pious to find a place of their own. Religions, in other words, involve homemaking. They construct a home - and a homeland". When a Malay Muslim faces the black cubical (kabaah) in the holy mosque in Mecca (Masjidil-haram) during the five obligatory prayers (solat), she simultaneously locates herself in her own geographical and social location in the (Muslim) world-and therefore in Malaysia. When a Malay Muslim does not eat pork and does not drink alcohol in the multicultural environment of his country, he distinguishes himself, at the same time, from Chinese or Indian Malaysians, for example, and thereby marks his position as a Muslim in a Muslim-majority nation-state. Hence, transregional connectivities from Malaysia to the Arabian Peninsula are ambiguous endeavours that are inherently formed by both longing for and

\footnotetext{
${ }^{3}$ https://www.crescentrating.com/magazine/opinion/3659/malaysias-prominent-role-in-halal-tourism.html, https://newsroom. mastercard.com/asia-pacific/press-releases/mastercard-crescentrating-global-muslim-travel-index-gmti-2019-indonesia-andmalaysia-take-the-top-positions-in-the-fast-growing-muslim-travel-market/, accessed 25 May 2020.

${ }^{4}$ This program addresses inbound tourism in Saudi Arabia. Until the launch of this program, only pilgrimage and business visas could be used to enter the country. See https://scth.gov.sa/en/Programs-Activities/Programs/Pages/AfterUmrahTourPro. aspx, accessed 3 May 2019.
} 
direction towards the desired centre of Islam. This entails both determining and stabilising the Self. 'Crossing and dwelling' become one.

The creation and expression of the Self and self-positioning open up the potential to assure and to convince oneself. This, in turn, can form a basis for self-confident developments that challenge stable social and placial orders. Malaysia as an 'old tiger' (Derichs 2007), i.e., an economically booming country since the 1980s, has contested the transregional Islamic centre-periphery metaphor and practice from its strong, entrenched Southeast Asian position. The halal hub thus dwells in the Malay Archipelago and crosses the oceans, especially the Indian Ocean, towards the Arabian Peninsula.

\section{The abaya economy}

The abaya is a sought-after female garment in Malaysia because it is highly associated with the holy land (haramain) (Thimm 2015, 2018). Centred in the midst of the Arabian Peninsula, Dubai plays a relevant role concerning the abaya due to its bustling fashion market targeting Muslims (Al-Qasimi 2010). This, in turn, has implications for forms of transregional design, marketing and shopping that radiates especially to Malaysia, where the abaya is not part of traditional attire and was introduced into everyday life only in the 2010s. Due to transregional connectivities between Malaysia and the Arabian Peninsula that people create and maintain as pilgrims, tourists and migrants, the abaya is designed, produced and consumed with its unique styles not only in Dubai but also in Malaysia.

In general, Malay Malaysian women wear the abaya differently than Arabian women do. The latter use the abaya as a closed black garment made of flowing nylon or polyester (Thimm 2015). The abaya is a long, ankle-length robe, and Arabic women commonly wear it over a long-sleeved and long-legged set of clothes, so that it covers these clothes completely. Hence, they wear it on top of their everyday clothes like jeans, skirts, long-sleeve shirts or blouses, and it is specifically worn outside the house. Based on this use, the abaya on the Arabian Peninsula is originally and usually open at the front. Additionally, women in the Gulf wear a headscarf (sheyla) in a matching design. Traditionally black in colour, both abaya and sheyla can have subtle ornaments. The social development of this type of clothing is regularly legitimised through references to the Qur'an, although the holy book does not explicitly mention a black, anklelength dress (Thimm 2015, 2018).

In contrast, Malaysian women wear more colourful abayas with more decorative elements. The understanding of this garment diverges drastically too: Malaysian women wear it as a one-piece dress and as an everyday garment both inside and outside the house. Furthermore, they do not wear it with a matching sheyla but instead accompany it with their colourful Malay headscarves (tudung). Given this, many of my respondents call the abaya either 'abaya' or 'jubah' interchangeably. The (female) jubah in Malaysia is a coloured dress worn by Malay Malaysians that can be simple or decorated. In terms of the cut, it looks the same as 'their' Malaysian form of abaya. The only difference is the colour: Whereas most of my Malay Malaysian and Arabian respondents identified an abaya as always being black, the jubah has at least one colour. The coloured jubah was never called 'abaya' during my fieldwork.

The synonymous use of jubah and abaya not only depicts a linguistic circumstance but furthermore hints at ideological entanglements between the two female garments beginning in the 1970s. During that time, the proselytizing revivalist dakwah movement gained strength, and various social groups challenged existing orders and practices, which eventually led to state Islamisation and politicisation of Islam (Ufen 2008: 120). Malay Malaysian women who were part of the dakwah movement first discovered the combination of a headscarf with a baju kurung (a patterned, [multi-] coloured two-piece dress consisting of a wide skirt and a wide blouse) (Ong 2003: 279; see Stivens 2006). Before, Malay Malaysian women had been widely wearing the colourful baju kebaya, among other things, which is a tight skirt and a tight, waisted blouse. The baju kurung, in contrast, was a loose alternative intended to cover the bodily silhouette. Around a decade later, female dakwah followers extensively started to wear the one-coloured jubah as a means to visually distance themselves from women attiring their bodies with colourful and patterned baju kurung, which had become a garment that represented a specifically Malay way of practicing Islam. Against this backdrop, first the baju kurung and then the jubah were significant contrasts to mark orthodox Muslim females. The current situation in which pious female Malay Malaysians embody their inner stance via an abaya directly connects with this process and explains the sartorial proximity between abaya and jubah. 
The oscillation between elements connoted as Muslim and as Malay currently culminates in how my respondents wore their abayas. Interestingly, according to my observations, the Malaysian-style appropriation of the Arabian abaya (wearing it as a dress rather than as a cloak; combining it with a coloured tudung and not with a black sheyla) has occurred across various socio-structural determinants in mainland Malaysia. During my phases of fieldwork, I observed Malay Malaysian women who attired themselves with abayas in cities such as KL and Kota Bahru, in towns such as Melaka and Ipoh, and in rural areas (kampungs) such as Kelantan and Terengganu. I saw females of different ages dressed in abaya, from adolescents to their mothers and grandmothers. Whether their educational background was in state or private Islamic schools, the abaya appeared. However, what united them was their specific design and style that slightly differs from the Arab original.

The differences between the female garments worn in Malaysia and in the Arab Gulf region as well as the differences in style of the garment are connected to different socio-cultural groups of consumers not within the regional but within the transregional sphere. This is exemplified through a detailed, ethnographically thick example from a particular Malaysian brand. When I met with 35-year-old Emily, the head of operations of Jazaa International, a Malaysian enterprise designing and selling abayas, on 26 August 2017, different abaya consumers were a particular issue. Our meeting took place in the company's showroom located in Bangsar, a primarily upper-middle-class neighbourhood in Kuala Lumpur. The showroom is set up in a 30-storey residential building where potential customers can see, touch and try on Jazaa International's self-designed and -tailored display items. Emily runs this firm with Haryati, a fashion designer, and together, they were planning to open their first shop in KL in the luxury Bangsar Shopping Centre in December 2017. Haryati founded the brand in 2014, when she opened their first and hitherto only shop in Dubai while living in Abu Dhabi between 2013 and 2017.

Surrounded by their unique abaya pieces, we sat on the chaise longue in the middle of the showroom and talked about their international abaya business between Dubai and Kuala Lumpur. Emily told me, "We wanted to reintroduce a very modest yet elegant wear, the abaya, as modern fashion. It is not appreciated enough, and people tend to view this way of dressing as traditional, oppressed and controlled". The abayas I could see on the clothes rails were long coloured dresses in navy blue, dusky pink or brown adorned with sequins, floral design, small shiny stones or opulent feathers; each was showcased with a headscarf in the corresponding design. Emily continued, "Here [in KL/Malaysia], people are fed up with the low-quality abayas from the Middle East; there are so many of them here. People already have these abayas. So now they look for something that really suits their taste; they want luxury abayas, premium abayas, because they have all these simple ones from the Middle East already". I raised the question of why this is so, assuming that few Malaysians can afford a trip to and an abaya from Dubai:

Because there are a lot of Malaysians living there [in Dubai] because their husbands are there. They just go to the markets, take pictures of all these different types of abayas and upload their pictures on Instagram. Then they ask people which one they like, and only then they buy it in the market for them. So there these women are re-sellers in Dubai. They go to the abaya market, the souq naif. This is where all the cheap abayas are. And of course, people here in Malaysia are also used to these cheap abayas because there are local [Malaysian] companies that try to make abayas. So that's why people now look at our [Jazaa International's] luxury abayas. They cost between 500 and 2000 Malaysian Ringgit. Ours are a good investment, you can wear them for 10 years. (26 August 2017)

Emily then took two of her company's pieces and asked me to touch them: one in navy blue with sparkling Swarovski stones and satin at the bottom, the other in lime green with ostrich feathers. I asked her whether their abayas followed the trends from Dubai. Emily clarified that they bring the fabric from Dubai, but they design the abayas themselves because they explicitly do not want to follow the trend in Dubai, "Because the Malaysian market is different. If we follow the Dubai trend too much, the abayas will not be sold here. Our collection for Dubai is 100 per cent different from our collection for Malaysia. ${ }^{5}$ We have the coloured and embellished pieces here. But in fact, it is not an abaya anymore. The coloured

\footnotetext{
${ }^{5}$ I was interested in where they sold more of their abayas, in Kuala Lumpur or in Dubai. Emily stated that in terms of numbers, they were selling more in Dubai, but in terms of revenue, more in KL, even though their shop in Dubai was located in a huge
} 
ones are actually a jubah [one-piece dress worn by Malay Malaysians], which is the same as a jallabiyah in Dubai" (26 August 2017).

She continued pulling out abayas, this time one with a tiger pattern on the upper part and a simple black section on the lower part of the dress. She revealed, "Malaysians will not wear [entirely] black, they will wear colours first and will wear black only if there is a special occasion for it, like a funeral". While showing me two predominantly black pieces with white embroidered patterns that were designed for the Dubai market, she commented,

The Malaysians hate it! This abaya doesn't look nice for Malaysians, it looks strange for them. Apart from the differences in the design and the colour, those abayas that follow the Arabian taste are all made by men. There isn't a single woman in the textile and trading market. The designers, tailors and traders are all male. Our abayas in KL are designed by women, it's about taste. (26 August 2017)

\section{Transregional abaya style}

Emily raised the issue that Malay Malaysian women usually prefer a different design and style than Arabic woman and explained that when in Dubai, Malaysian customers usually visit the abaya market souq naif for their purchases. During fieldwork, I spent time there on a regular basis. Souq naif, located in Deira near the famous Baniyas Square in the old part of Dubai, is a market where people can buy ready-made abayas, but also fabric, incense or cosmetics. Most of the customers are women, whereas all the salespersons are men from South or Central Asia. The customers are predominantly touristsmost of them from Saudi Arabia, others from Egypt, Bahrain, Qatar, Sudan or Malaysia.

When talking to the salesmen, it became obvious that every customer group has its own abaya taste. Ahmad from Afghanistan, who had worked at the souq naif as a vendor since 2011, showed me the different designs. Abayas with colourful elements and that are 'shiny', with opulent glittering stones, for example, were the most sought-after abayas for Malaysians, Indonesians and Singaporeans. Malaysians furthermore liked one particular type of abaya that Dubai is famous for: the so-called 'butterfly style'. This abaya is tailored with a wide skirt. The abayas in souq naif cost between $50 \mathrm{Dhs}$ and $160 \mathrm{Dhs}$, which is around 50 to 160 Malaysian Ringgit. Malaysians usually paid around 130 Dhs, Ahmad explained, and this corresponded with my observations. As mentioned above, Emily stated that her $a b a-$ yas at Jazaa International cost between 500 and 2000 Ringgit, raising the question of how these designs, prices, products and customer groups relate to one another.

Like Ahmad, Emily pointed out that women from Dubai and Malaysia follow their own tastes, which are embedded in cultural customs and habits. The Malay Malaysians of this study, in fact, imagined a piece of clothing they call 'Dubai abaya' that they (want to) get at souq naif or comparable stores. According to the vendors at that market, Malaysians aspired to own abayas with a particular design: bold colours and shiny stones. My respondents called this type of design 'bling bling'. The abaya worn in Dubai, however, has a '100 per cent different' design from the abayas worn by Malay Malaysians, as Emily illustrated (26 August 2017). This led me to the observation that there is a uniquely Malaysian style of abaya. Designers like Emily adapt their production lines according to the customer's needs and desires, and thereby transform the original Arabic style of the abaya into a Malaysian one.

Obviously, different product and customer groups exist over transregional space, relating to the design, the price range and the customer's regional and class origins. Consequently, different types of and submarkets for the abaya exist in both regions. Malaysian designers, producers and consumers have developed their own abaya market that complements and simultaneously challenges the market in the UAE. Incorporated into the local halal industry, Malaysian brands such as Jazaa International underscore a shift of religious hegemony that has been evident in the fashion realm for some time. As a result, this shift 'de-centers' (Derichs 2015) the Islamic centre, i.e., the Hejaz and the wider Arabian Peninsula.

This de-centring is not only important empirical evidence but simultaneously forms an epistemological tool to re-frame existing research categories and their inherent power relations. Derichs (2015: 33) argues,

shopping mall and they did not have a proper shop in KL at that time. "But the competition is higher there in Dubai, that's why" (26 August 2017). 
[d]e-centering (...) trains scholars to depart from container categories and territorialized units, so as to more aptly map the field of inquiry. (...) It also takes into account the significance of shifting the view from the centers to the peripheries of knowledge production, and from conventionally demarcated regions to non-demarcated regions.

Following this perspective, the Malaysian market for Muslim fashion is not only regarded as a sphere that comprises a variation in abaya style. Rather, it can be observed and understood as a socio-political and economic realm that is part of broader 'power geometries' (Massey 2001) across space and time, i.e., of conditions in which people are products of their contexts but also have agency and power in relation to those contexts of transregional connectivities. Given this, I understand the transregional abaya industry situated in Malaysia with its designers, producers and consumers as part of broader dynamics that intervene in powerful world orders.

\section{Conclusion}

Practices and meanings related to the abaya in Malaysia are embedded in a Muslim world order. Whereas Mecca, in particular, and the Arabian Peninsula, in general, are considered to be the spiritual centre of Islam, Malaysia places itself at the Muslim periphery. This sacred place-making influences human and material movement on the basis of production and consumption: Material objects and goods (e.g., abaya) are connected with modern and/or spiritual meaning due to their place of origin. The Malay Malaysian women of this study purchased abayas on their sojourns to the Arabian Peninsula, especially in Dubai, with its growing market for Muslim fashion. On the basis of transregional experiences between 'the Islamic periphery' and 'the Islamic centre', the design, purchase and wearing of abayas lead to transformative potentials of sacred landscaping. Whereas the Hejaz and the Arab region as a whole have been the religious centre ever since the beginning of Islam, Malaysia has developed itself as a commercial centre that is at the forefront of Islamic-connoted products, i.e., the halal market. This role within the Muslim world forms the background for self-confident Muslim fashion designers, producers and consumers, in this case of the abaya, to gather the courage, creativity and resources necessary to appropriate a benchmark of Muslim clothing and even adapt it to local taste. This practice, in turn, strengthens Malaysia's position in the global halal market.

Drawing on an understanding of 'religion as culture' rather than of 'institutionalized religion', Aliakbar Jafari and Ahmet Süerdem (2012: 61) clarify that "in their everyday life consumption practices, Muslims (re)interpret religious guidelines in different ways, and refer to Islam as a transcendental set of guidelines to make better sense of their cultural practices in different ways". This (re)interpretation via consumption not only happens on the level of social actors as consumers, but furthermore affects longlasting and stable narratives and ideologies. Transregional connectivities between what are now the nation-states of Malaysia, the United Arab Emirates and Saudi Arabia are not unilateral when it comes to hierarchal placial and spatial mapping of the Muslim world. The transregional Muslim fashion market transcends this geographical and social order towards a more negotiated and challenged set of localities.

Acknowledgements. I am most thankful for the Olympia Morata Fellowship in support of young female professors by the University of Heidelberg, the Research Fellowship by the German Research Foundation (DFG) (funding number 324628960) and the Postdoctoral Fellowship by the Initiative for young scholars of the University of Hamburg that have provided financial support for the larger project from which this paper grew.

\section{References}

Abaza, Mona. 1996. "Islam in South-east Asia: Varying impact and images of the Middle East." In Islam, Muslims and the Modern State: Case-Studies of Muslims in Thirteen Countries, edited by Hussin Mutalib and Taj ul-Islam Hashmi, 139151. London/New York: Macmillan.

Abaza, Mona. 1999. "Vorstellungen über Geschlecht und Islam - Der Mittlere Osten und Malaysia. Übereinstimmungen, Entlehnungen und Wechselbeziehungen." In Der neue Islam der Frauen. Weibliche Lebenspraxis in der globalisierten Moderne. Fallstudien aus Afrika, Asien und Europa, edited by Ruth Klein Hessling, Sigrid Nökel, and Karin Werner, 277296. Bielefeld: Transcript. 
Abaza, Mona. 2007. “More on the shifting worlds of Islam. The Middle East and Southeast Asia: A troubled relationship?” The Muslim World 97(3): 419-436.

Abaza, Mona. 2011. “Asia imagined by the Arabs." In Islamic Studies and Islamic Education in Contemporary Southeast Asia, edited by Kamaruzzaman Bustamam-Ahmad and Patrick Jory, 1-27. Kuala Lumpur: Yayasan Ilmuwan.

Aiedah Abdul Khalek. 2018. "Entrepreneurship and the halal wave in Malaysia." In Global Entrepreneurship and New Venture Creation in the Sharing Economy, edited by Norhayati Zakaria and Kaushal Leena, 191-205. Hershey USA: IGI Global.

Aiza Maslan Baharudin. 2014. “Hajj and the Malayan experience, 1860s-1941.” Kemanusiaan 21(2): 79-98.

Al-Qasimi, Noor. 2010. "Immodest modesty: Accommodating dissent and the 'Abaya-as-fashion in the Arab Gulf States." Journal of Middle East Women's Studies 6(1): 46-74.

Ansary, Tamim. 2010. Die unbekannte Mitte der Welt: Globalgeschichte aus islamischer Sicht. Frankfurt/Main: Campus.

Anthias, Floya. 2012. "Transnational mobilities, migration research and intersectionality: Towards a translocational frame." Nordic Journal of Migration Research 2(2): 102-110.

Basch, Linda, Nina Glick Schiller, and Cristina Szanton Blanc. 1997. "From immigrant to transmigrant: Theorizing transnational migration." In Transnationale Migration, edited by Ludger Pries, 121-140. Baden-Baden: Nomos.

Bauder, Harald. 2014. "The possibilities of open and no borders." Social Justice 39(4): 76-96.

Boccagni, Paolo. 2012. "Revisiting the 'transnational' in migration studies: A sociological understanding." Revue européenne des migrations internationales [European Review of International Migrations] 28(1): 33-50.

Bonfanti, Sara. 2016. "Dislocating Punjabiyat: Gendered mobilities among Indian diasporas in Italy." In Bounded Mobilities: Ethnographic Perspectives on Social Hierarchies and Global Inequalities, edited by Miriam Gutekunst, Andreas Hackl, Sabina Leoncini, Julia Sophia Schwarz, and Irene Götz, 183-205. Bielefeld: Transcript.

Bunnell, Tim. 2016. From World City to the World in One City: Liverpool through Malay Lives. Chichester: John Wiley \& Sons.

Chong, Terence. 2005. Modernization Trends in Southeast Asia. Singapore: ISEAS.

Department of Statistics, Malaysia. 2016. Current Population Estimates, Malaysia, 2014-2016. Available at: https://www.dosm. gov.my/v1/index.php?r=column/ctheme\&menu_id=L0pheU43NWJwRWVSZklWdzQ4TlhUUT09\&bul_id=OWlxdEVoYlJCS 0hUZzJyRUcvZEYxZz09 (accessed 24 October 2017).

Derichs, Claudia. 2007. "Malaysia in 2006: An old tiger roars.” Asian Survey 47(1): 148-154.

Derichs, Claudia. 2014. “Alternative Perspektiven auf Weltordnung und Konzepte von Entwicklung." Neue politische Literatur 59(2): 255-272.

Derichs, Claudia. 2015. “Shifting epistemologies in area studies.” Middle East - Topics \& Arguments 4: 29-36.

El-Tayeb, Fatima. 2016. Undeutsch: Die Konstruktion des Anderen in der postmigrantischen Gesellschaft. Wiesbaden: Transcript.

Federal Constitution Malaysia. n.d. http://www.agc.gov.my/agcportal/uploads/files/Publications/FC/FEDERAL\%20CONSTITUTION \%20ULANG\%20CETAK\%202016.pdf (last accessed 2 January, 2021).

Feener, R Michael, and Terenjit Sevea, eds. 2009. Islamic Connections: Muslim Societies in South and Southeast Asia. Singapore: ISEAS.

Fischer, Johan. 2008. Proper Islamic Consumption: Shopping among the Malays in Modern Malaysia. Copenhagen: NIAS.

Fischer, Johan. 2018. “Forging new Malay networks': Imagining global halal markets." Focaal - European Journal for Anthropology 80(1): 91-104.

Frisk, Sylva. 2009. Submitting to God: Women and Islam in Urban Malaysia. Copenhagen: NIAS.

Gielis, Ruben. 2009. "A global sense of migrant places: Towards a place perspective in the study of migrant transnationalism." Global Networks 9(2): 271-287.

Glick Schiller, Nina, and Noel B. Salazar. 2013. "Regimes of mobility across the globe." Journal of Ethnic and Migration Studies 39(2): 183-200.

Göler, Daniel, and Zaiga Krišjāne. 2016. “Elusive migration systems: Shifting from transnationalism to transregionalism.” In Global Change and Human Mobility, Advances in Geographical and Environmental Sciences, edited by Josefina DomínguezMujica, 25-36. Singapore: Springer.

Gunn, Geoffrey C. 2008. Singapore and the Asian Revolutions. Macau: Gunn.

Hannam, Kevin, Mimi Sheller, and John Urry. 2006. “Editorial: Mobilities, immobilities and moorings.” Mobilities 1(1): 1-22.

Harvey, David. 1969. Explanation in Geography. London: Arnold.

Hefner, Robert W. 2001. "Introduction: Multiculturalism and citizenship in Malaysia, Singapore, and Indonesia." In The Politics of Multiculturalism: Pluralism and Citizenship in Malaysia, Singapore, and Indonesia, edited by Robert W. Hefner, 1-58. Honolulu: University of Hawai'i Press.

Huff, W.G. 1994. The Economic Growth of Singapore: Trade and Development in the Twentieth Century. Cambridge: Cambridge University Press.

Jafari, Aliakbar, and Ahmet Süerdem. 2012. “An analysis of material consumption culture in the Muslim world.” Marketing Theory 12(1): 61-79.

Kahn, Joel S. 1996. “The middle class as a field of ethnological study.” In Malaysia. Pandangan Kritis. Esei Panghargaan untuk Syed Husin Ali, edited by Muhammad Ikmal Said, and Zahid Emby, 12-33. Petaling Jaya: Persatuan Sains Social Malaysia.

Kessler, Clive S. 2001. "Alternative approaches, divided consciousness: Dualities in studying the contemporary Southeast Asian middle classes." In Southeast Asian Middle Classes: Prospects for Social Change and Democratisation, edited by Abdul Rahman Embong, 31-45. Bangi: Penerbit Universiti Kebangsaan Malaysia.

King, Geoffrey R. 2001. “The coming of Islam and the Islamic period in the UAE.” In United Arab Emirates: A New Perspective, edited by Ibrahim Al Abed, and Peter Hellyer, 70-87. London: Trident. 
Knott, Kim. 2014. The Location of Religion: A Spatial Analysis. Abingdon: Routledge.

Lafaye de Micheaux, Elsa. 2017. The Development of Malaysian Capitalism: From British Rule to the Present Day. Petaling Jaya: SIRD.

Lefebvre, Henri. 1991 [1974]. The Production of Space. Wiley: Blackwell.

Löw, Martina. 2001. Raumsoziologie. Frankfurt/Main: Suhrkamp.

Marcus, George. 1995. "Ethnography in/of the world system: The emergence of multi-sited ethnography." Annual Review of Anthropology 24: 95-117.

Massey, Doreen. 2001. Space, Place, and Gender. Minneapolis: University of Minnesota Press.

Meyer, Birgit, and Dick Houtman. 2012. "Introduction: Material religion - How things matter." In Things: Religion and the Question of Materiality, edited by Dick Houtman, and Birgit Meyer, 1-23. New York: Fordham University Press.

Müller, Dominik. 2014. Islam, Politics and Youth in Malaysia: The Pop-Islamist Reinvention of PAS. London and New York: Routledge.

Norani Othman. 1998. "Islamization and modernization in Malaysia: Competing cultural reassertions and women's identity in a changing society." In Women, Ethnicity and Nationalism, edited by Rick Wilford, and Robert L. Miller, 170-192. London: Routledge.

Ong, Aihwa. 2003. “State versus Islam: Malay families, women's bodies, and the body politic in Malaysia." In Islam, Gender and the Family, edited by Bryan S. Turner, 262-288. London: Routledge.

Ooi Keat Gin. 2009. "Politics divided: Malaysia-Singapore relations.” In Across the Causeway: A Multi-dimensional Study of Malaysia-Singapore Relations, edited by Takashi Shiraishi, 27-51. Singapore: ISEAS.

Rudnyckyj, Daromir. 2019. Beyond Debt. Chicago and London: University of Chicago Press.

Salazar, Noel. 2016. "Keywords of mobility: What's in a name?" In Keywords of Mobility: Critical Engagements, edited by Noel B. Salazar, and Kiran Jayaram, 1-12. New York: Berghahn.

Saravanamuttu, Johan. 2001. "Is there a politics of the Malaysian middle class?” In Southeast Asian Middle Classes: Prospects for Social Change and Democratisation, edited by Abdul Rahman Embong, 103-118. Bangi: Penerbit Universiti Kebangsaan Malaysia.

Schroer, Markus. 2006. Räume, Orte, Grenzen: Auf dem Weg zu einer Soziologie des Raums. Frankfurt/Main: Suhrkamp.

Sen, Arijit, and Lisa Silverman. 2014. "Introduction: Embodied placemaking: An important category of critical analysis." In Making Place: Space and Embodiment in the City, edited by Arijit Sen, and Lisa Silverman, 1-18. Bloomington: Indiana University Press.

Sharifa Zaleha Syed Hassan. 2001. "Islamisation and urban religious identity: The middle class of Bandar Baru Bangi." In Southeast Asian Middle Classes: Prospects for Social Change and Democratisation, edited by Abdul Rahman Embong, 119138. Bangi: Penerbit Universiti Kebangsaan Malaysia.

Stivens, Maila. 2006. “Family values' and Islamic revival: Gender, rights and state moral projects in Malaysia.” Women's Studies International Forum 19: 354-367.

Syed Jaymal Zahiid. 2016. “Forum explores creeping ‘Arabisation' among Malays,” Malay Mail, 24. May 2016. Available at: https://www.malaymail.com/news/malaysia/2016/05/24/forum-explores-creeping-arabisation-among-malays/1126197 (last accessed 2 January 2021).

Tagliacozzo, Eric. 2013. The Longest Journey: Southeast Asians and the Pilgrimage to Mecca. Oxford: Oxford University Press.

Thimm, Viola. 2015. "Die arabische abaya in Malaysia: Verhandlungen von muslimischen Kleidungspraktiken, weiblicher Körperlichkeit und Modernität." Paideuma 61: 95-116.

Thimm, Viola. 2017. Commercialising Islam in Malaysia: Ziarah at the Intersection of Muslim Pilgrimage and the Market-Driven Tourism Industry. UKM Ethnic Studies Paper Series No. 56, December. Bangi: Institute of Ethnic Studies.

Thimm, Viola. 2018. "Embodying and consuming Muslim pilgrimage: Gendered shopping and clothing practices by Malaysian women on 'umrah and ziarah Dubai." Asian Anthropology 17(3): 185-203.

Thimm, Viola. 2021. "Under male supervision? Islamic belief and nationality as basis for Muslim women's pilgrimage." In Muslim Women's Pilgrimage to Mecca and Beyond: Reconfiguring Gender, Religion, and Mobility, edited by Marjo Buitelaar, Manja Stephan-Emmrich, and Viola Thimm, 19-35. Abingdon/New York: Routledge.

Thimm, Viola. Forthcoming. "Gendered pilgrimage: Hajj and umrah from women's perspectives." Journal of Contemporary Religion.

Tweed, Thomas A. 2008. Crossings and Dwellings: A Theory of Religion. Cambridge and London: Harvard University Press.

Ufen, Andreas. 2008. "Die komplexe Dynamik der Islamisierung. Der malaysische Islam im Spannungsfeld von Staat, politischer Gesellschaft und Zivilgesellschaft." In Religion und Identität: Muslime und Nicht-Muslime in Südostasien, edited by Fritz Schulze and Holger Warnk, 111-136. Wiesbaden: Harrassowitz.

Werlen, Benno. 1987. Gesellschaft, Handlung und Raum: Grundlagen handlungstheoretischer Sozialgeographie. Stuttgart: Steiner. Werlen, Benno. 2010. Gesellschaftliche Räumlichkeit 2: Konstruktion geografischer Wirklichkeiten. Stuttgart: Steiner.

Yeoh Sen-Guan. 2016. "Religious pluralism and pilgrimage studies in West (Peninsular) Malaysia." In New Pathways in Pilgrimage Studies: Global Perspectives, edited by Dionigi Albera, and John Eade, 68-88. New York and London: Routledge.

Cite this article: Thimm V (2021). Muslim Fashion: Challenging Transregional Connectivities between Malaysia and the Arabian Peninsula. TRaNS: Trans -Regional and -National Studies of Southeast Asia 9, 117-128. https://doi.org/10.1017/ $\operatorname{trn} .2021 .1$ 